\title{
Bolívia em tempo de pandemia: crise humanitária e conflito político
}

\author{
Bolivia in a time of pandemic: humanitarian crisis and political conflict
}

\author{
Fabio Sousa Mendonça de Castro \\ Doutorando em Economia Política Mundial pela UFABC \\ .castro@ufabc.edu.br
}

\author{
Igor Fuser \\ Doutor em Ciência Política - USP \\ Professor da UFABC \\ igor.fuser@ufabc.edu.br
}

\begin{abstract}
Resumo: Na Bolívia, a pandemia da Covid19 coincidiu com um período conflituoso em sua história: um governo de facto instalado sob a presidência da direitista Jeanine Áñez, após o golpe de estado de novembro de 2019 que forçou a renúncia de Evo Morales. A falta de legitimidade dos novos governantes e sua incapacidade de conter os contágios e cuidar da população provocaram uma crise sanitária de grandes proporções. Os sucessivos adiamentos das eleições presidenciais prometidas para 2020 acirraram o confronto entre o governo de Áñez e os partidários do Movimento ao Socialismo. O artigo descreve e analisa a complexa interação entre as questões sanitárias e a luta política que culminou com o regresso da esquerda ao comando do Estado, com a vitória de Luis Arce nas eleições de outubro de 2020.
\end{abstract}

Palavras-chave: Bolívia, Covid-19, golpe.

\begin{abstract}
In Bolivia, the Covid-19 pandemic coincided with a conflicted period in its history: a de facto government installed under the presidency of right-wing Jeanine Áñez, following the November 2019 coup d'état that forced Evo Morales to resign. The lack of legitimacy of the new rulers and their inability to contain the contagions and care for the population caused a major health crisis. The successive postponements of the presidential elections promised for 2020 have intensified the confrontation between the Áñez government and the supporters of the Movement to Socialism. The article describes and analyzes the complex interaction between health issues and the political struggle that culminated in the left's return to state command, with Luis Arce's victory in the October 2020 elections.
\end{abstract}

Keywords: Bolivia, Covid-19, coup d'etat. 


\section{Introdução}

Desde fevereiro/março de 2020 o mundo enfrenta os efeitos de uma pandemia que se configura como o primeiro grande evento sanitário em escala global da humanidade. Suas implicações têm colocado em xeque o modelo de sociedade em que estamos organizados. Uma ideia muito corrente é a de que se trata de um evento democrático, pois atingiria todos os seres humanos da mesma forma, mas um olhar mais atento revela que os impactos da pandemia são muito mais trágicos nos países do Sul Global, a parte mais pobre e periférica do mundo, do que nos países ricos do Norte, e, em cada país, as mortes e os contágios crescem em proporção inversa à condição econômica das populações. As vacinas estão concentradas nos países ricos ${ }^{1} \mathrm{e}$ o método do lockdown é muito mais eficiente em países em que o tecido social não está esgarçado pela desigualdade.

O objetivo deste artigo é assinalar como os efeitos da pandemia contribuíram para a desestabilização social nos países mais pobres, a partir do olhar sobre a Bolívia. A América Latina e o Caribe já registravam, no momento em que concluímos o presente artigo, mais de 44 milhões de casos de Covid-19 e mais de 1,5 milhão de mortes causadas pela pandemia (CEPAL, 2021). Esses números impressionantes demonstram o nível da crise humanitária que ainda segue sem uma solução.

Os países latino-americanos sofrem de uma crônica condição que pressiona sua população à miséria e ao desamparo em serviços essenciais, como a saúde, o que num momento crítico como este se refletiu na sucessão de cenários de catástrofe em vários países, como no caso equatoriano, em que corpos de pessoas mortas pela Covid-19 foram vistos largados nas ruas $^{2}$. Na maioria dos demais países da região, a pandemia provocou o colapso do sistema de saúde, pois não havia leitos em unidades de atendimento intensivo suficientes, muito menos os respiradores necessários para combater os efeitos da doença. Para Svampa (2020) a evolução da pandemia expôs as limitações estruturais e conjunturais da América Latina.

\footnotetext{
${ }^{1}$ De acordo com avaliações apresentadas por integrantes do Painel Global sobre Equidade da Vacina contra COVID-19, iniciativa conjunta do Programa das Nações Unidas para o Desenvolvimento (PNUD), da Organização Mundial da Saúde (OMS) e da Escola de Governo Blavatnik da Universidade de Oxford, nos países mais ricos a economia está se recuperando mais rapidamente da Covid-19, enquanto os países mais pobres não conseguiram nem mesmo vacinar seus profissionais de saúde e a população mais vulnerável e podem não atingir os níveis de crescimento pré-COVID-19 até 2024 (PNUD Brasil, 2021).

${ }^{2} \mathrm{O}$ chamado colapso funerário. Ver: https://www.bbc.com/portuguese/internacional-52129845
} 
A Organização Mundial da Saúde (OMS) indicou para o mundo a única defesa possível: distanciamento social, a higienização constante das mãos e dos objetos manipuláveis, e o uso de máscaras de proteção - enquanto laboratórios de pesquisa ao redor do mundo trabalhavam para desenvolver de forma inédita, pela velocidade necessária, um imunizante para conter a disseminação do vírus. Evidentemente, o impacto sanitário provocou a paralisação da economia, o que se refletiu numa recessão global de 3,5\% no ano de 2020 (WORLD BANK). Mas o impacto da crise tem perspectivas diferentes nas distintas regiões, pois depende da capacidade e da vontade política dos governantes de atuarem para combater o vírus e evitar uma degeneração do tecido social.

No caso dos países chamados desenvolvidos, foi adotada uma estratégia de transferência de renda para garantir que a economia não desmoronasse e a população pudesse seguir as orientações de segurança da OMS. Nos países pobres, por sua vez, que possuem um sistema econômico deteriorado, em que há um desemprego estrutural e uma predominância do trabalho baseado na informalidade, além, na maioria dos casos, de um Estado incapaz de reagir adequadamente aos desafios impostos, a população se encontrou pressionada entre a necessidade de trabalhar para sobreviver e a orientação de proteção da OMS.

Esta condição dificultou fortemente o combate à pandemia nos países da América do Sul e da América Latina em geral, que sucumbiram à Covid-19 e mergulharam em situações sanitárias devastadoras. A quantidade de mortes por milhão de habitantes na América do Sul já se contabiliza em 2.713,22, enquanto na União Europeia, por exemplo, onde a mortandade por Covid-19 no início da pandemia foi muito elevada, essa proporção é de 1.858,80 (OUR WORLD IN DATA) ${ }^{3}$.

Se compararmos em um gráfico a evolução das mortes por coronavírus, nas duas regiões - Gráfico 1, é perceptível que os europeus sofreram com as ondas de contaminação da pandemia, mas seu combate é muito mais eficiente do que na América do Sul, que carrega uma trajetória muito longa de mortes, sem redução expressiva da tendência.

\footnotetext{
${ }^{3}$ Dados da atualização: November 22, 2021. Ver: https://ourworldindata.org/covid-cases?country=
} 
Gráfico 1 - Média móvel de mortes por COVID-19 na América do Sul e União Européia

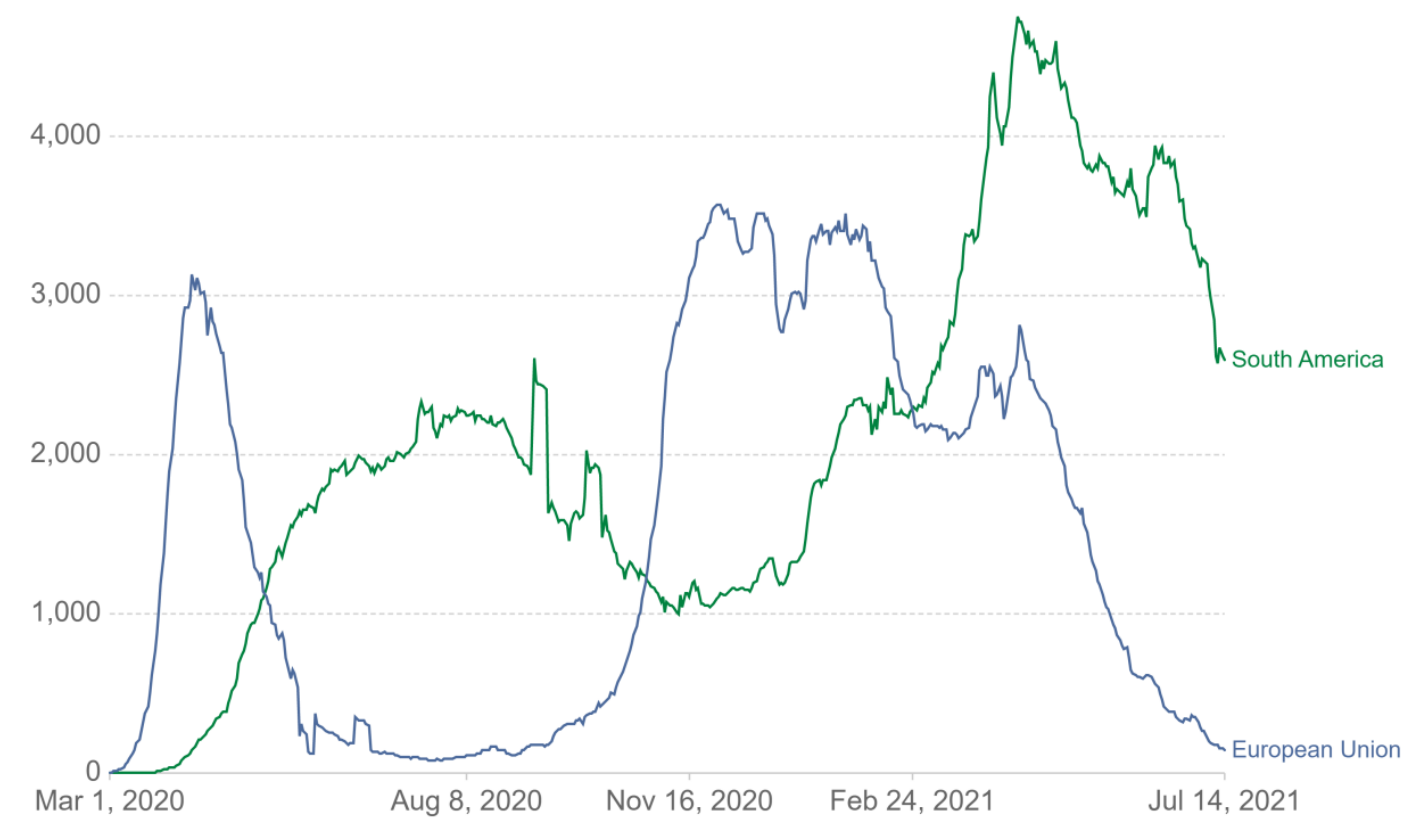

Fonte: Our World in Data. COVID-19 dataset.

A situação se configurou ainda mais complicada porque os governos de alguns países sul-americanos, envolvidos em processos de polarização política intensos, adotaram a estratégia de politizar a pandemia a fim de alcançar seus objetivos. No Brasil, por exemplo, o governo federal adotou a perspectiva negacionista, a fim de criar uma narrativa de que é preciso deixar o povo faminto trabalhar para salvar a economia, promovendo medicamentos ineficazes ao combate à pandemia (CAPONI et al., 2021), o que agravou o desastre brasileiro, ao ponto de suscitar acusações de genocídio contra o governo do presidente Jair Bolsonaro ${ }^{4}$. No caso da Bolívia, a princípio, a pandemia foi encarada numa perspectiva alarmista, sendo usada como pretexto para aplicação de

\footnotetext{
${ }^{4}$ A Comissão Parlamentar de Inquérito instaurada no Senado brasileiro para investigar a conduta do governo Bolsonaro perante a pandemia concluiu que as provas obtidas "demonstraram sobejamente que o governo federal foi omisso e optou por agir de forma não técnica e desidiosa no enfrentamento da pandemia do novo coronavírus, expondo deliberadamente a população a risco concreto de infecção em massa" (Gl, 2021). Quando o Brasil atingiu a marca de 500 mil mortes, o ex-presidente Lula foi um dos atores políticos que chamaram a tragédia de genocídio. Ver: https://noticias.uol.com.br/saude/ultimasnoticias/redacao/2021/06/19/lula-500-mil-mortos.htm
} 
políticas autoritárias e prolongar a duração de um governo instaurado por meio de um golpe de estado, o que no fim se mostrou um fracasso ${ }^{5}$.

De maneira geral, os governantes dos países da América do Sul tiveram seu prestígio abalado pela dificuldade de enfrentar a pandemia. Em alguns casos a legitimidade das forças políticas no poder foi colocada em xeque, levando a grandes confrontos político-sociais, como na Colômbia, ou a rápidos processos de desprestígio do governo federal (os casos do Brasil na gestão de Bolsonaro e, também, da Argentina na gestão de Alberto Fernández, de centro-esquerda), e até mesmo a uma mudança político-ideológica no comando do Estado, através de eleições que levaram ao poder a oposição.

No Equador, um dos países mais duramente atingidos pela Covid, os índices de rejeição ao governo se tornaram tão elevados que convenceram o presidente Lenín Moreno a desistir de concorrer à reeleição. No caso do Peru, o candidato de esquerda Pedro Castillo (um opositor aos sucessivos governos neoliberais naquele país) venceu as eleições por uma margem muito pequena sobre sua rival ultra-direitista Keiko Fujimori, mas enfrentou dificuldades em ter a vitória reconhecida em meio a varias tentativas de impugnação da eleição e, até o momento da redação deste artigo, enfrentava um grave déficit de governabilidade. Por fim, o caso mais paradigmático dos países em que houve eleições presidenciais em tempos de pandemia é o da Bolívia. O país, no momento da eclosão da Covid-19, estava imerso havia poucos meses em um governo de facto fundamentalista cristão ultra-direitista, cuja gestão da pandemia foi um desastre e abriu caminho para o retorno da esquerda em menos de um ano. É esse o processo que vamos examinar neste artigo.

\section{O Golpe de Estado de 2019}

\footnotetext{
${ }^{5}$ Hummel e colaboradores (2020) procuraram desenvolver uma interpretação das consequências da pandemia nos primeiros seis meses na Bolívia como um esforço enorme de aparentar uma neutralidade científica, chegando à conclusão de que políticas públicas de alarme da situação não são suficientes para combater a pandemia, se não se considerarem outro fatores - o que deixa a análise marcada pelo vazio de sentido. Entretanto, um cruzamento de dados simples a partir de outras publicitações da autora desmistifica tal vazio, pois a mesma não poderia ver que o fator governo golpista foi um desastre para o país, tendo em vista sua filiação anti-masista, anotada em textos e entrevistas ao jornal The New York Times $(2019 ; 2020)$.
} 
A Bolívia chegou a um limite histórico do processo revolucionário iniciado com a "Guerra da Água" em 2000, que levou ao governo o Movimento ao Socialismo (MAS) em 2006, na figura do presidente Evo Morales. Um "processo de mudança"6 que nacionalizou os recursos naturais e transformou o Estado em protagonista da economia boliviana, promovendo um largo processo de redução das desigualdades, fortalecimento econômico nacional e construção de infraestrutura.

De acordo com dados oficiais, durante o período em que Morales exerceu a presidência a pobreza na Bolívia diminuiu de 59,9\% a 34,6\%, enquanto a pobreza absoluta caiu de 38,2\% a 15,2\%. O analfabetismo foi erradicado, graças à aplicação do programa educacional cubano "Yo, sí, puedo" ("Sim, eu posso"). A telefonia celular passou a alcançar todos os rincões do país, com a universalização do acesso à Internet, e um teleférico foi inaugurado ligando La Paz à cidade vizinha de El Alto, um conglomerado urbano indígena com mais de um milhão de habitantes (FUSER, 2016: 93).

Por outro lado, as condições gerais de saúde na Bolívia permaneceram precárias. Uma tabela elaborada pela CEPAL (com base em dados da OMS e da Global Health Expenditure Database) situa os gastos públicos em saúde na Bolívia em 2018 no patamar dos US\$ 500 por habitante, uma cifra inferior à média da América Latina e do Caribe (CEPAL, 2021: 5).

Evo Morales ganhou com folga todas as eleições presidenciais de que participou (em 2005, 2009 e 2014), antes do conturbado processo eleitoral de outubro de 2019, em que sua vitória por uma ínfima parcela da votação sobre o oposicionista Carlos Mesa ${ }^{7}$ suscitou denúncias de fraude que serviram de estopim para a bem-sucedida intentona golpista da direita boliviana.

\footnotetext{
${ }^{6}$ Em espanhol, proceso de cambio, forma como o governo boliviano na gestão de Morales denominou o projeto político do MAS. Os direcionamentos da mudança se estabeleceram a partir da chamada agenda de outubro (de 2003) durante a chamada Guerra do Gás, que desafiou o neoliberalismo e colocou em evidência a luta pela nacionalização dos recursos naturais e a dimensão étnica das lutas sociais na Bolívia. Com a vitória eleitoral do MAS em 2005 e com a promulgação da Constituição Política do Estado, em 2009, os direcionamentos das políticas públicas do governo Morales se condensaram na ideia do vivir bien. Essa concepção, inspirada nas tradições e no modo de vida dos povos originários de regiões andinas, é encarada de diferentes maneiras por atores políticos e correntes de pensamento conflitantes na América Latina, mas as controvérsias em torno do tema extrapolam os objetivos deste artigo.

7 Pela Constituição boliviana, um candidato é considerado vencedor nas eleições presidenciais, sem a necessidade de um segundo turno, caso obtenha mais de $50 \%$ dos votos válidos ou um mínimo de $40 \%$ e uma diferença de ao menos 10\% em relação ao segundo colocado. Em 25 de outubro de 2019, o Tribunal Supremo Eleitoral (TSE), a autoridade eleitoral do país, publicou os resultados finais da eleição, em que Morales obteve $47,08 \%$ contra 36,51\% para Mesa, ou seja, uma diferença de aproximadamente 10,5 pontos percentuais.
} 
Essas denúncias de fraude principiaram devido a uma interrupção do sistema de contagem de votos durante a apuração das eleições, quando os resultados indicavam a realização de segundo turno. Todavia, faltava a contagem dos votos das regiões com maior presença de camponeses, em que o MAS tem mais força política. Os resultados do sistema de contagem rápida foram divulgados $24 \mathrm{~h}$ depois, indicando a vitória em primeiro turno de Evo Morales e abrindo o caminho para grandes mobilizações urbanas da classe média que pediam anulação da eleição devido a supostas fraudes que, entretanto, jamais foram comprovadas (BBC NEWS, 2019). Por outro lado, existem fortes indícios de que foram construídas e veiculadas com a intenção de criar as condições políticas internas e o respaldo internacional para a derrubada de Morales diante do fracasso de seus opositores em derrotá-lo nas urnas.

Quatro dias antes da divulgação dos resultados finais, uma missão de observadores eleitorais enviados pela Organização dos Estados Americanos (OEA) para acompanhar as eleições bolivianas em todos os departamentos (Estados) do país expressou sua "profunda preocupação e surpresa com a mudança drástica e de difícil explicação na tendência dos resultados preliminares revelados após o fechamento das urnas" (JOHNSTON, 2019). Essa declaração, ao colocar sob suspeita a validade da apuração, impulsionou as mobilizações, em uma escala crescente de violência, de opositores civis, agentes policiais e milícias de extrema-direita, culminando com a renúncia forçada de Morales e de todos os seus eventuais sucessores constitucionais.

A renúncia, em 10 de novembro de 2019, ocorreu após o presidente receber uma "recomendação" pública de renúncia feita pelo chefe supremo das Forças Armadas, que se recusara ostensivamente a enfrentar a rebelião em curso, colocando sob risco de morte os integrantes do governo, os líderes do Poder Legislativo e do MAS - e o próprio Morales.

Até hoje a conduta da OEA (e do seu secretário-geral, Luis Almagro, que fez declarações em apoio à derrubada de Morales), é motivo de controvérsias. O atual governo boliviano, em agosto de 2021, cobrou publicamente a apresentação de um relatório final da auditoria da OEA, uma vez que o único documento divulgado - a declaração aqui mencionada - não corresponde a uma avaliação conclusiva sobre o processo eleitoral. Isso representaria o descumprimento do acordo firmado previamente entre a organização e as autoridades bolivianas e tornaria inválidas as acusações de fraude (TELAM, 2021). 
A OEA considera o caso como encerrado e recusou convite do governo do presidente boliviano Luis Arce de enviar representantes para debater o assunto publicamente (TELAM, 2021). De concreto, o que se sabe é que a inversão da tendência na contagem eleitoral verificada nos últimos $12 \%$ dos votos apurados, aproximadamente, corresponde ao padrão de preferências políticas expressas anteriormente naquelas seções eleitorais - regiões camponesas, distantes da capital, e nas quais o MAS conta tradicionalmente com forte apoio - em diversas eleições anteriores (JOHNSTON, 2019).

De acordo com o relatório de uma equipe de investigadores enviada por um think tank estadunidense logo após a eleição, as irregularidades apontadas são comuns em processos eleitorais legítimos no mundo inteiro, especialmente em regiões rurais onde os eleitores e próprios os responsáveis pelas seções eleitorais possuem baixo grau de escolaridade, não indicam má fé ou intenção de adulterar a votação e, de qualquer modo, mesmo na pior das hipóteses, a quantidade de votos envolvida nas situações mencionadas pela missão da OEA seria insuficiente para alterar o resultado da disputa presidencial (LONG et al., 2019). Além disso, este mesmo relatório da OEA foi desmentido por um instituto de pesquisas estadunidense, que atestou a inconsistência estatística de tal relatório (IDROBO et al., 2020).

Mas é preciso compreender este relatório da OEA no contexto de um processo de desestabilização que se iniciou em 2016. Os desgastes do "processo de mudança", em meio a importantes contradições internas e a sucessivas derrotas dos governos progressistas na América Latina, abriram espaço para o fortalecimento da direita boliviana. Em 21 de fevereiro de 2016, Evo Morales foi derrotado (por 51,3\% contra $48,7 \%$ ) no referendo sobre a possibilidade de se candidatar para a disputa de um quarto mandato presidencial. O pleito foi marcado por uma campanha agressiva da oposição e da mídia, que procurou desgastar a figura de Morales a partir de acusações que envolvem a sua conduta moral, em um intenso processo de disseminação de fake news. Essas acusações, cuja falsidade nos pontos mais relevantes só ficou plenamente clara após o referendo, foram consideradas por grande parte dos analisas como decisivas para a sua derrota (RIVERA, 2019).

Morales não aceitou a derrota. A dificuldade - real ou alegada - de construir politicamente um nome para a sucessão presidencial levou o MAS a insistir na candidatura de Morales, logrando reverter a situação em um processo judicial, muito questionado, que garantiu sua candidatura para o pleito de 2019. Esta controversa 
manobra política foi habilmente explorada pela oposição, que utilizou um slogan eleitoral de forte apelo ("El pueblo dijo no", ou seja, "o povo disse não"), apoiando-se no sentimento popular, fortemente arraigado na Bolívia, que vincula a ideia da democracia com a da renovação das pessoas no exercício dos cargos políticos mais importantes. Com a aproximação das eleições, o discurso opositor foi se tornando cada vez mais agressivo, sinalizando claramente que a direita boliviana não aceitaria o resultado das eleições caso Morales saísse vencedor (FUSER; CASTRO, 2020).

Por sua vez, os movimentos sociais e políticos em defesa do "processo de mudança", durante os eventos que antecederam o golpe de estado em 2019, se mostraram pouco mobilizados em comparação com os fortes movimentos difusos prógolpe que tomaram as ruas de importantes cidades do país demandando a renúncia de Evo Morales. Apesar de ficar cada vez mais evidenciado um movimento orquestrado para derrubar o MAS, este fato corrobora com a compreensão dos limites históricos em que havia chegado o "processo de mudança", naquela altura bastante enfraquecido após quase 14 anos de governo.

A alegada necessidade permanente de conciliar com as velhas oligarquias e a euforia do crescimento econômico impulsionado no período de 2006 a 2014 pelos altos preços da commodities (entre elas o gás natural, principal produto de exportação boliviano), com a causa nobre de retirar milhões de pessoas da miséria, sobrepesou a estratégia desenvolvimentista frente às demandas históricas de um país plurinacional que não necessariamente almeja viver o sonho ocidental de civilização. É evidente que não há respostas fáceis para lograr esta construção de equilíbrios e o percurso da história "agradou gregos, mas desagradou troianos".

Grandes projetos de infraestrutura, importantes para romper com a miséria colonial, foram planejados, em alguns momentos, sem a anuência de parte dos movimentos sociais organizados, principalmente indígenas das chamadas terras baixas, no leste boliviano, onde são mais rarefeitas as tradições de luta política que alicerçaram a ascensão e posterior exercício do poder pelo MAS. Neste sentido, controvérsias enormes marcaram o governo de Evo Morales, com destaque para o projeto (até hoje pendente de execução) de construir uma rodovia atravessando o Território Indígena e Parque Nacional Isiboro-Sécure (TIPNIS), uma área de proteção ambiental onde vivem 12 mil pessoas, integrantes de diversos povos originários, num contexto em que grande número de atores sociais da esquerda boliviana (muitos deles, inicialmente, favoráveis à ascensão do MAS ao governo) denunciaram a suposta incoerência entre a conduta das 
autoridades e os valores do "vivir bien" (SCHAVELZON, 2011; FUNDACIÓN TIERRA, 2012).

Enquanto uma parcela dos movimentos sociais acusava o governo de enveredar por uma deriva autoritária, o MAS e os intelectuais do campo oficialista interpretavam que os adversários do projeto da rodovia estavam sendo cooptados por organizações não-governamentais (ONGs) que supostamente se colocavam em defesa do meio ambiente, mas que no fundo pretendiam desestabilizar o governo Morales (GARCÍA LINERA, 2011).

A dificuldade em lidar com as tensões resultantes de tal processo e a conturbada gestão dos conflitos, sob cenas de repressão policial chocantes no contexto de um governo que se apresenta como expressão dos movimentos sociais populares, tornaram o evento do TIPNIS um momento marcante no longo processo de deslegitimação do governo Morales. Há um universo de publicações discutindo o tema e Dos Santos (2018) aponta que este pode ser considerado um ponto de inflexão na relação do governo com os movimentos sociais.

Neste sentido, apesar de seguir avançando o projeto de transformar o país para "viver bem", o governo foi paulatinamente se desgastando com suas bases históricas. O fenômeno é bastante compreensível tendo em vista as contradições presentes no "processo de mudança", entre elas a que envolve, de um lado, a busca do desenvolvimento entendido no sentido convencional de avanço tecnológico, ampliação da infraestrutura e melhoria das condições materiais da população e, do outro lado, o reconhecimento pleno dos direitos das populações indígenas e a vigência de novas relações, de respeito, com a chamada Pacha Mama, a "Mãe Terra". A direita soube utilizar estes desgastes para avançar sua capacidade de pressionar o governo, culminando no golpe de estado em novembro de $2019^{8}$.

Entretanto, aparentemente, o golpe não saiu como planejado. Tal qual aconteceu em outros países da região, na Bolívia se pretendia um golpe suave, pelas vias institucionais, sem os banhos de sangue que marcaram o chamado "ciclo militar" das

\footnotetext{
${ }^{8}$ Há grandes controvérsias sobre se o que aconteceu foi um golpe cívico-militar ou uma reação da sociedade civil a uma suposta fraude eleitoral do MAS. Lehoucq (2020) e Zibechi (2019) entendem que as manifestações contra as supostas fraudes nas eleições foram um movimento popular legítimo. Entretanto, o percurso histórico tem demonstrado que houve efetivamente um Golpe de Estado e, inclusive há discussões ao redor do tema de uma interferência externa interessada em acessar as riquezas naturais bolivianas, principalmente o lítio (CASTRO et al., 2021). Stefanoni (2020), editor da revista de ensaios Nueva Sociedad, ligada à social-democracia alemã, se situa entre os intelectuais fortemente críticos ao governo Morales que, não obstante, endossam a ideia de que ocorreu, inequivocamente, um golpe de estado na Bolívia.
} 
décadas de 1960 e 1970 na América do Sul (SILVA, 2018). Mas os protagonistas da rebelião direitista de outubro/novembro de 2019 não contavam que, apesar de desgastado, Evo Morales ainda guardava uma enorme força social capaz de resistir aos intentos golpistas dissimulados por um discurso liberal de defesa da democracia e da lisura do processo eleitoral. No fim das contas, o golpe se desenvolveu por meio da força bruta, com cenas estarrecedoras de violência contra integrantes e partidários do MAS e atos hediondos de racismo anti-indígena, amplamente documentados pela mídia estrangeira.

Dois massacres, cometidos poucos dias após a tomada do poder pelos golpistas, romperam com a inércia das divisões dos movimentos sociais e conformaram a rearticulação das organizações das camadas desfavorecidas na resistência ao golpe. Em Sacaba (Cochabamba) e Senkata (El Alto), em novembro de 2019, centenas de pessoas ficaram feridas e 36 pessoas morreram vítimas de disparos de armas de fogo na pressão policial a manifestantes contra o golpe ${ }^{9}$. Este governo de facto assinou um decreto garantindo impunidade aos militares no enfrentamento aos movimentos sociais - uma verdadeira autorização para matar (MANETTO, 2019). Estes crimes ainda estão sob investigação judicial no atual governo boliviano. Estes dois episódios de banho de sangue se tornaram bandeiras do movimento social que, unido, exigia a renúncia daquela que se tornaria conhecida como "a primeira ditadora da história da América Latina" (LAMBERT, 2019) e a convocação imediata de novas eleições.

Com a deposição de Morales, quem assumiu a presidência foi Jeanine Áñez, uma senadora ultradireitista do Departamento (unidade federativa equivalente ao Estado no Brasil) de Beni, com uma trajetória política turbinada por um discurso religioso cristão exaltado e fundamentalista, ao qual agregava um ostensivo revanchismo, de cunho racista, contra as políticas favoráveis à maioria indígena adotadas sob a hegemonia do MAS. Áñez não estava na fila sucessória presidencial, mas seu nome foi decidido, à margem das regras constitucionais, em um acordo extraparlamentar ${ }^{10}$ orquestrado por membros da Igreja Católica junto à diplomacia brasileira, britânica e da

\footnotetext{
${ }^{9}$ Esses confrontos foram marcados por extrema violência e chocaram o mundo quando manifestante tentaram se aproximar do palácio do governo com caixões em que estavam os corpos dos mortos nos conflitos, restando esses caixões no chão após a reação dos militares. Ver: https://www.pagina12.com.ar/305985-bolivia-a-un-ano-de-la-masacre-sacaba-recuerda-a-sus-victima.

${ }^{10}$ Tal acordo foi ratificado pelo Tribunal Constitucional Plurinacional, o mesmo que autorizou Morales a concorrer a um quarto mandato, fortalecendo a posse de Áñez para um governo transitório. Entretanto há um complexo processo jurídico sobre este fato, que questiona a legitimidade de tal ratificação. Ver: https://www.justicia.gob.bo/portal/noticia_modal.php?new $=$ on $2 \mathrm{q}$
} 
União Européia, militares bolivianos e a oposição ao MAS, imediatamente após o amotinamento policial e a renúncia forçada do presidente Evo Morales ${ }^{11}$. O presidente renunciou atendendo a uma "sugestão" do chefe do Estado-Maior da Forças Armadas, general Williams Kalliman, seguida pela renúncia do vice-presidente Álvaro García Linera, do presidenta do Senado, Adriana Salvatierra, e do presidente da Câmara dos Deputados, Victor Borda ${ }^{12}$. O governo Áñez foi marcado pelo autoritarismo, pela falta de legitimidade e pela gestão desastrosa do combate à pandemia do novo coronavírus, em meio a escândalos de corrupção.

\section{A pandemia na Bolívia}

O coronavírus atingiu duramente a Bolívia. Durante a primeira onda da pandemia, o país sul-americano apresentou uma das taxas mais altas, no mundo inteiro, de contágio por milhão de habitantes, com 100 mil casos registrados em agosto de 2020, numa população de 11,6 milhão de habitantes (LA REPÚBLICA, 2021). Há dois motivos principais para isso.

Em primeiro lugar, a precariedade do sistema de saúde pública boliviano, com sua crônica carência de recursos financeiros, o que deixa grande parte da população excluída do atendimento médico e os hospitais públicos funcionando permanentemente no limite de sua capacidade. Essa situação levou o país em 2020 a um colapso sanitário assim que o número de pacientes de Covid-19 com necessidade de internação superou as poucas vagas disponíveis. Cerca de $80 \%$ da população ativa trabalha na economia informal a ampla maioria sem acesso a qualquer plano de saúde (EL PAÍS, 2021). A segunda razão tem a ver com a conduta ineficiente e irresponsável do governo da presidenta de facto Jeanine Áñez, com sua demora em tomar as medidas necessárias para enfrentar a pandemia e o caráter eleitoreiro de várias delas.

A chegada do vírus à Bolívia já era prevista com antecedência de várias semanas, devido à sua presença nos países vizinhos e ao rápido alastramento da

\footnotetext{
11 Segundo um os articuladores do golpe, Waldo Albarracín, reitor da Universidad Mayor de San Andrés, em La Paz, um acordo "lo más cercano posible a la Constitución". Ver: https://www.larazon.com/nacional/2021/06/02/reunion-en-la-ucb-scarpellini-mesa-y-quiroga-eran-el-poder-antes-queanezl

${ }^{12}$ Foram realizadas várias reuniões na Universidade Católica da Bolívia, que só vieram à tona em junho de 2021. Ver: https://www.nodal.am/2021/06/la-iglesia-entrega-informe-sobre-su-rol-en-el-golpe-deestado-y-revela-que-mesa-puso-a-anez/
} 
pandemia em outras partes do globo. Mas o governo, ainda assim, não foi capaz de implementar a tempo os protocolos de segurança voltados para detectar o vírus em viajantes que ingressavam no país e isolá-los para evitar o contágio (HERNÁNDEZ BERMÚDEZ, 2020). Tampouco foram tomadas as providências necessárias para preparar as instituições de saúde, comprar respiradores, máscaras e equipamentos de proteção aos profissionais da saúde, ampliar o número de leitos hospitalares com medidas de emergência e pôr em prática ações de auxílio econômico para garantir a segurança alimentar das camadas desprivilegiadas da população, amplamente majoritárias. A presidenta de facto aguardou mais de seis meses para convocar as autoridades subnacionais e as principais entidades da sociedade civil para, só então, discutir medidas coordenadas para o enfrentamento da pandemia.

Os primeiros casos de Covid-19 na Bolívia foram confirmados no dia 10 de março de 2020 nas cidades de Oruro e Santa Cruz: duas mulheres de 60 e 64 anos, respectivamente, que haviam chegado recentemente de viagens à Itália, país que naquele momento apresentava índices especialmente elevados de presença do vírus. Dois dias depois, o governo declarou “emergência nacional” pela presença do Covid-19, por meio do Decreto Supremo $\mathrm{n}^{\mathrm{o}} 4.179$ (BOLÍVIA, 2020a). A estratégia adotada atendia às orientações da Organização Mundial de Saúde (OMS), enfatizando o isolamento social e a restrição dos deslocamentos da população. A quarentena total foi implantada em 22 de março, instituída pelo Decreto Supremo 4.199 (BOLÍVIA, 2020b), que determinou que todos permanecessem em seu domicílio, sem sair à rua. Somente uma pessoa por família tinha permissão para se locomover no espaço público, apenas uma vez por semana, no período das 7 horas da manhã ao meio-dia, com a finalidade exclusiva abastecer o próprio lar com os alimentos e insumos indispensáveis, obtidos nas cercanias da residência. Quem violasse a quarentena estava sujeito a punições que podiam chegar a 10 anos de prisão (QUISPE BARRA, 2021). A primeira morte ocorreu no dia 29 de março, em Santa Cruz. A vítima, uma mulher de 78 anos, contraiu o vírus por meio de um familiar que havia chegado do exterior.

As manifestações públicas da presidenta foram marcadas pelas referências religiosas presentes no discurso dos líderes do golpe de 2019. Logo no início da crise, Áñez se dirigiu à população nos seguintes termos: "Queridos bolivianos, peço a vocês que nos unamos em uma oração permanente. Neste domingo se inicia uma quarentena total e peço que possamos realizar um jejum em oração, arrependimento e fé, para que essa seja a nossa maior arma de luta contra essa enfermidade. Que Deus bendiga a 
Bolívia" (HERNÁNDEZ BERMÚDEZ, 2020). Já se notava, naquele momento, o despreparo do governo para enfrentar o desafio sanitário. Em lugar de coordenar os esforços para as ações no terreno sanitário, Áñez - que se lançou como candidata nas eleições presidenciais apesar de ter prometido anteriormente que não o faria - usava seu cargo para buscar votos, com ações eticamente controversas como o uso de helicópteros para "abençoar" as maiores cidades durante a Semana Santa (MIRANDA, 2020).

O principal candidato oposicionista à presidência, Luis Arce, ex-ministro da Economia nas gestões do MAS, recomendou a Áñez que pedisse ao governo cubano o envio de médicos e medicamentos produzidos na ilha para reforçar o combate à Covid19. A sugestão foi recusada e Arce, acusado de fazer demagogia com fins eleitorais. O vice-ministro da Saúde, Erwin Viruez, garantiu que "os médicos bolivianos estão plenamente preparados para atender a esta ou a qualquer outra contingência" (HERNÁNDEZ BERMÚDEZ, 2020).

\section{Uma catástrofe sanitária}

A primeira quarentena durou 15 dias, logo seguida por outros 15 dias, e logo adiante mais quinze. E assim se passaram os meses de março, abril e maio. As estatísticas dos contágios e das mortes subiam em ritmo alarmante. A mídia começava a veicular denúncias de médicos afirmando que faltavam luvas, máscaras e todo tipo de Equipamentos de Proteção Individual (VILLCA, 2020). Logo no início, Áñez estabeleceu medidas de auxílio econômico às famílias mais pobres a fim de ajudá-las a sobreviver durante as quarentenas, mas essas iniciativas se relevaram insuficientes. A primeira delas foi um pagamento, concedido uma única vez, de 500 bolivianos (o equivalente a 72 dólares estadunidenses), para cada filho matriculado em escola primária pública. Também foi adiada a cobrança de impostos de pessoas físicas e de pequenas empresas. Proibiu-se o corte dos serviços de água, eletricidade e gás por falta de pagamento durante o período da pandemia (SPUTNIK, 2020).

Imediatamente, irromperam protestos contra o alcance limitado dessas medidas, claramente insuficientes para garantir a sobrevivência da população desprivilegiada da cidade e do campo. O Centro de Estudos Jurídicos e de Pesquisa Social denunciou que os povos originários estavam excluídos das medidas contra a Covid-19 e, pior ainda, corriam risco de morte por falta de alimentos e de remédios (CEJIS, 2020). Pressionado, o governo ampliou a ajuda emergencial, com o anúncio de um novo bônus, no valor de 
400 bolivianos (US\$ 58), para mulher grávidas, aposentados e deficientes físicos, além de um aumento no auxílio às famílias com crianças no ensino básico público. Em paralelo, foi estabelecido um Bônus Universal, também no valor de 500 bolivianos, para todos os cidadãos maiores de 18 anos desprovidos de qualquer ganhou econômico regular, ou seja, que não recebem nenhuma renda do Estado, nem salário do setor público ou do privado (MINISTERIO DE LA PRESIDENCIA, 2020).

O contexto de instabilidade política presente desde a anulação das eleições de outubro de 2019, com a renúncia forçada do presidente Evo Morales, dificultou a adoção de uma estratégia eficiente para conter a pandemia. A iminência de eleições presidenciais e parlamentares - sucessivamente adiadas - manteve os atores políticos em estado de permanente conflito, enquanto as autoridades se mostravam mais interessadas em fortalecer sua posição no embate eleitoral do que articular as medidas para enfrentar a crise sanitária, que se agravava em escala catastrófica.

O Poder Executivo, nas mãos de Ánez, enfrentava problemas de governabilidade porque o MAS, graças à habilidade tática dos seus parlamentares em lidar com a nova situação política, manteve o controle político da Câmara dos Deputados e do Senado, com mais de dois terços das cadeiras em ambas as casas legislativas. As eleições gerais, marcadas inicialmente para 3 de maio, foram postergadas no dia 21 de março por decisão do juiz Salvador Romero, presidente do Tribunal Supremo Eleitoral (TSE), que justificou a medida com base na crise sanitária. Por meio de acordo entre a maioria dos partidos, estabeleceu-se 6 de setembro como a nova data (CAZARRÉ, 2020).

Mesmo que não tenha sido essa a intenção, o adiamento revelou-se funcional para os candidatos da direita boliviana, diante das sondagens eleitorais dos dois primeiros meses de 2020, que situavam o MAS em primeiro lugar e próximo de uma vitória no primeiro turno da disputa presidencial. A pandemia, nesse cenário, oferecia às forças conservadores a oportunidade de ganhar tempo enquanto buscavam um meio de reverter a desvantagem, buscando a impugnação jurídica de Arce ou, ao menos, o desgaste de sua imagem pública ${ }^{13}$. Na propaganda dos candidatos de direita, afirmavase que o culpado pelo descontrole da pandemia era Morales, que durante seu período no governo não teria investido na construção de hospitais, preferindo, em lugar disso, construir estádios de futebol (MIRANDA, 2020).

\footnotetext{
13 O governo de Áñez e os candidatos dos partidos direitistas tentaram impugnar o registro eleitoral do MAS e de seu candidato, sem sucesso.
} 
Com o ex-presidente Evo Morales exilado no México (e, logo depois, na Argentina), o MAS escolheu como candidato presidencial Luis Arce, que em quase todo o período Morales (2006-2019) foi o ministro da Economia. A imagem pública Arce como um excelente administrador sinalizou a aposta em um nome que, além de agradar aos militantes do MAS, tinha o potencial de disputar o voto de eleitores centristas, a princípio mais atraídos a votar no principal candidato opositor, Carlos Mesa, um neoliberal que impulsionou a escalada golpista de 2019, sem se comprometer com o extremismo das milícias de extrema-direita lideradas por Luis Fernando Camacho, um protagonista central no golpe de 2019 e atual governador do Departamento de Santa Cruz.

Mesa, dono de uma grande empresa de comunicação, era o vice-presidente em outubro de 2003 quando o presidente Gonzalo Sánchez de Lozada, de orientação política neoliberal, fugiu para os Estados Unidos após massacrar manifestantes que reivindicavam a nacionalização das jazidas de gás natural. Foi a chamada "Guerra do Gás". Mesa assumiu o governo, mas renunciou dois anos depois, em meio a uma segunda "Guerra do Gás" - a crise política provocada pela sua recusa em assinar, conforme demandavam os movimentos sociais de esquerda, uma lei, votada em plebiscito e aprovada pelo Congresso, com a nacionalização do gás boliviano. Abriu-se, naquele contexto, um impasse institucional que culminou com a realização das eleições antecipadas em que se saiu vitorioso o principal líder dos movimentos sociais, Evo Morales, com 53\% dos votos. Em 2020, Morales comandou a campanha masista a partir do exílio na Argentina. Tentou disputar uma vaga de senador pelo Departamento de Cochabamba, mas teve sua candidatura bloqueada pela justiça eleitoral, por pressão do governo golpista.

Além de Arce, Mesa e Áñez, outro nome de destaque na corrida presidencial de 2020 foi o Camacho, líder da extrema-direita racista de Santa Cruz. Durante a turbulenta ofensiva opositora que culminou com a renúncia forçada de Evo em novembro de 2019, Camacho ingressou no gabinete presidencial com uma Bíblia na mão, para simbolizar a "inspiração cristã" do levante direitista, enquanto, nas ruas, seus partidários queimavam a Wiphala - bandeira indígena multicolor adotada na Constituição do Estado Plurinacional da Bolívia como um símbolo tão importante quanto a bandeira nacional. As eleições estavam marcadas, como nas vezes anteriores, pela polarização entre as forças pró-MAS e anti-MAS. 
Desde o início estava claro que, salvo por algum expediente jurídico que deixasse o MAS fora da disputa, o único meio de impedir que a esquerda reconquistasse nas urnas o poder que lhe havia sido arrebatado no golpe era a unificação eleitoral das forças políticas conservadoras que se aliaram contra o governo de Morales. Essa era uma tarefa complicada, seja pelas ambições políticas envolvidas, seja pela rivalidade regional que divide a Bolívia entre a região andina, marcada pela forte presença indígena, no oeste, onde se situa La Paz, e as planícies do leste, a região da Meia Lua, onde se destaca a cidade de Santa Cruz, reduto da elite branca do agronegócio e da direita mais agressiva. Mesa, com sua força concentrada no oeste, principalmente entre a classe média urbana, despontava como o candidato mais competitivo entre os adversários do MAS.

\section{Governo abalado por escândalo de corrupção}

As chances eleitorais de Ánez desmoronaram, irreversivelmente, com o surgimento de um escândalo de corrupção envolvendo a compra superfaturada de respiradores para pacientes graves de Covid-19, causando aos cofres públicos um prejuízo calculado em cerca de US\$ 5 milhões (MOLINA, 2020). Em maio, a Assembleia Legislativa Plurinacional instalou uma Comissão Parlamentar de Inquérito (CPI) para investigar os indícios de irregularidades na importação, da Espanha, de 170 respiradores, comprados pelo governo boliviano ao preço de US\$27.683 cada um e que, por serem inadequados ao tratamento de Covid-19, jamais chegaram a ser utilizados. Constatou-se o envolvimento do ministro da Saúde, Marcelo Narvajas, que foi preso e destituído do cargo (RAMOS, 2020). Dono de clínicas privadas em La Paz, Narvajas já era um personagem polêmico ao ser indicado por Áñez. Durante o governo de Morales, notabilizou-se pela ferrenha oposição ao projeto oficial de construir 47 hospitais que serviriam de alicerce à instalação, na Bolívia, do Sistema Único de Saúde (SUS), usando como modelo a rede sanitária pública do Brasil. Narvajas também foi um dos líderes da greve dos médicos bolivianos contra o governo de Morales, mobilização que causou a morte de 16 pessoas por falta de cuidados hospitalares.

Àquela altura, o colapso do sistema sanitário boliviano já chamava a atenção da mídia internacional, que veiculou imagens de cadáveres de vítimas da Covid-19 estendidos numa via pública em Cochabamba porque os hospitais, lotados, já não puderam recebê-los para ministrar os devidos cuidados médicos (LA POLÍTICA ON 
LINE, 2020). Em Santa Cruz, a televisão local levou ao ar a cena dramática de uma morte por coronavírus ao vivo, exibindo um doente que, em estado grave, tinha sido recusado por cinco hospitais. Em Oruro, dezenas de mortos pela pandemia foram sepultados numa vala comum, por falta de espaço nos cemitérios e de estrutura para os serviços funerários, enquanto em Cochabamba ruas foram bloqueadas por caixões vazios, ali colocados por familiares de pessoas falecidas para demandar às autoridades que recolhessem os cadáveres em suas casas (ALIAGA, 2020). "Nosso sistema de saúde, tanto o setor estatal quanto o privado, entraram em colapso logo no início da pandemia", disse à agência de notícias Deutsche Welle o médico Fernando Patiño, um dos mais prestigiados oncologistas bolivianos. "Muitas pessoas faleceram sem diagnósticos nem assistência médica” (MAYER, 2020).

As críticas à conduta de Áñez perpassavam toda a sociedade boliviana, extrapolando os meios políticos e a disputa eleitoral. Ganharam grande repercussão as declarações do médico Adrián Ávila, presidente da Sociedade Boliviana de Medicina Crítica y Terapia Intensiva. Juntamente com muitos outros especialistas, ele vinha fazendo, desde a chegada da pandemia, em março, dramáticas advertências sobre as limitações do sistema de saúde e sua inadequação para enfrentar a Covid-19. Em agosto, voltou a público para denunciar que o quadro permanecia inalterado, apesar da catástrofe sanitária que devastava o país. De acordo com os dados apresentados por Ávila, a Bolívia contava, no mês de março, com 490 leitos de terapia intensiva, um número muito inferior aos 1.600 recomendados para uma população de 11,6 milhões de habitantes. Passados quase cinco meses, o país só havia aumentado sua disponibilidade de leitos em UTI para 520. Na avaliação do cientista político Fernando Mayorga (2020), "a dupla condição de presidenta e candidata deixou de ser uma vantagem para Áñez e a estratégia oficialista perdeu o rumo". 
Gráfico 2 - Média móvel de casos confirmados de COVID-19 na Bolívia até as eleições de 18 de outubro de 2020

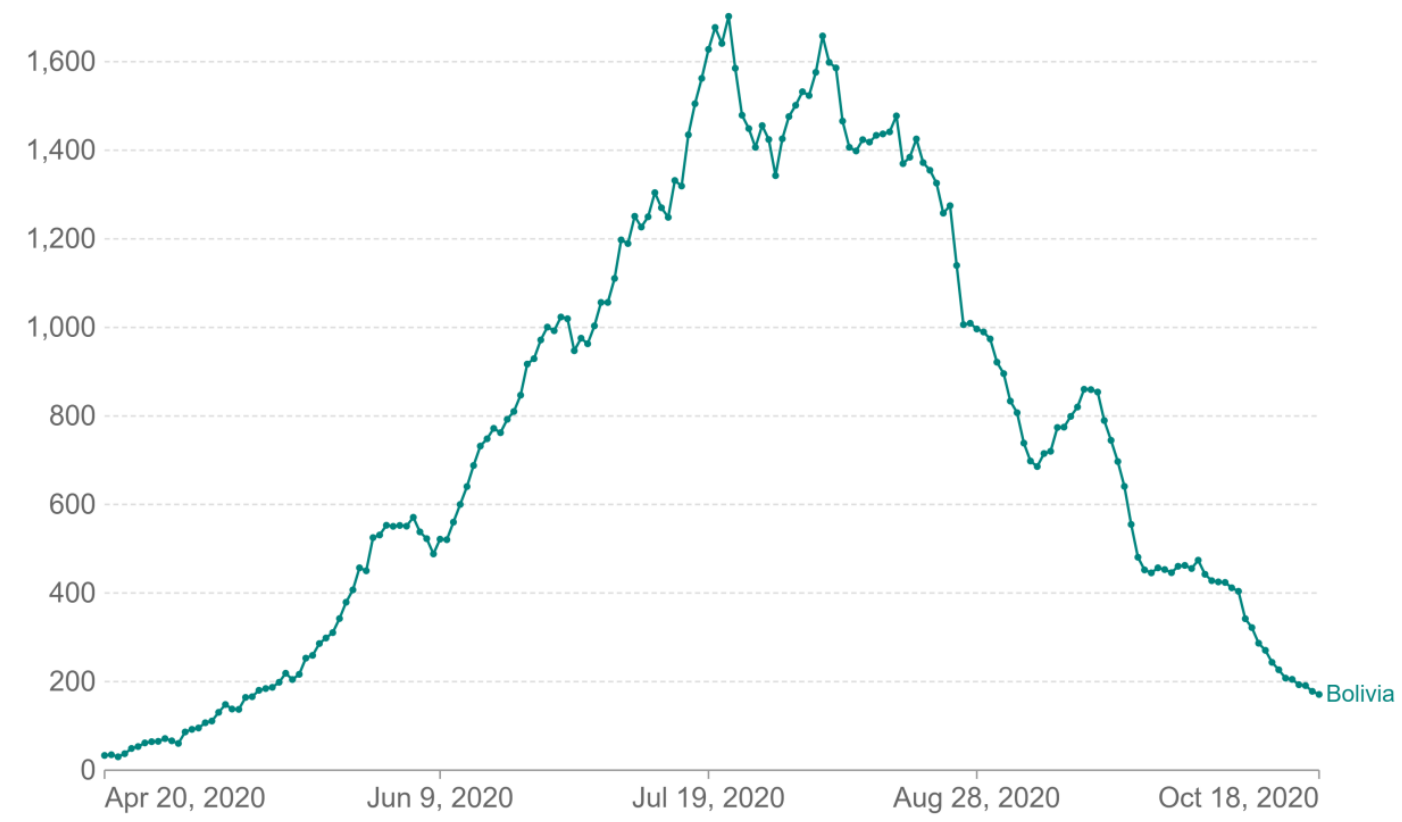

Fonte: Our World in Data. COVID-19 dataset.

Os meses mais críticos na expansão descontrolada da pandemia, durante o governo de facto, foram julho e agosto - Gráfico 2 acima -, coincidindo com a escalada na tensão política devido a um novo adiamento das eleições gerais, para 18 de outubro, sempre com a justificativa da crise sanitária. Desta vez, a mudança da data foi recebida com desconfiança e resistência pelos movimentos sociais ligados ao MAS, que interpretaram a sucessão de prorrogações como uma tática do governo golpista para fortalecer sua própria candidatura, legitimando o golpe de 2019 e criando condições para levar adiante a agenda política do governo Áñez, ultraliberal e alinhada à política externa dos EUA.

A mudança política na Bolívia teve entre suas consequências a adesão do país ao Grupo de Lima (uma aliança de governos direitistas latino-americanos contra o governo venezuelano de Nicolás Maduro, articulada pelos EUA) e o rompimento das relações diplomáticas com países em situação de conflito com os EUA, entre eles Cuba e o Irã (MACNELLY, 2021). No plano econômico, o governo de facto iniciou o 
desmantelamento do modelo nacional-desenvolvimentista do período anterior, indicando a privatização de empresas estatais, especialmente no setor da energia elétrica, e revisando contratos com empresas estrangeiras de petróleo e gás natural.

\section{Protagonismo político dos movimentos sociais}

Em resposta a esse novo adiamento das eleições - adotado de maneira "unilateral e arbitrária" (RODRÍGUEZ, 2020), conforme denunciou o líder cocalero Andrónico Rodríguez, ou seja, sem consulta aos políticos opositores -, os militantes do MAS recorreram ao seu tradicional método de mobilização por meio do bloqueio das estradas por piquetes de camponeses, indígenas e sindicalistas urbanos. Durante doze dias, na primeira quinzena de agosto, a Central Operária Boliviana (COB) e as organizações sociais agrupadas no Pacto de Unidade do MAS paralisaram as principais rodovias do país.

A administração do transporte rodoviário registrou 77 pontos de bloqueio, principalmente nos arredores de La Paz, Oruro, Cochabamba e Potosí, o que levou o governo acusar os opositores de provocar a morte de pacientes de Covid-19 que não conseguiram chegar aos hospitais a tempo de receber atendimento. Ocorreram, em muitos casos, confrontos com grupos de partidários do governo que tentaram desalojar os manifestantes por meio da força, até mesmo com o uso de armas de fogo. Em um desses incidentes, no departamento de Santa Cruz, três camponeses foram feridos a bala. O motivo aparente dos conflitos era a data das eleições, mas na realidade o que levou camponeses e sindicalistas a se mobilizarem foi o descontentamento generalizado com o governo de Áñez.

Esses protestos foram decisivos para solidificar uma ampla aliança de forças sociais dispostas a pressionar pelo retorno da democracia. Nas palavras de Juan Carlos Huarachi, secretário-executivo da COB, "o povo está pedindo (ao governo de Ánez) para respeitar a democracia, respeitar os serviços de saúde, respeitar a educação e respeitar nossa dignidade" (MACNELLY, 2021).

$\mathrm{Na}$ segunda metade de setembro, quando já se aproximava a chamada "reta final" das eleições, as pesquisas indicavam que Arce tinha apoio para alcançar os 40\% de votos suficientes para ganhar a eleição no primeiro turno, uma vez que seu oponente mais próximo, Mesa, contava com apenas 26\%. A divulgação dessa pesquisa levou Áñez a se retirar da disputa, em 17 de setembro, quando estava em quarto lugar, com 
cerca de $10 \%$, e em queda nas intenções de voto. Em discurso pelas redes sociais, ela conclamou os bolivianos a se unirem ao redor do candidato que tivesse mais chances de derrotar o MAS. "Se não nos unirmos, Morales volta", alertou. Em seus últimos dias na presidência, Áñez concedeu ilegalmente 3.400 hectares de terras públicas para seu ministro da Economia, Branko Marinkovic, que havia liderado em 2008 uma tentativa frustrada de golpe contra Morales (MACNELLY, 2021).

No momento da desistência de Áñez, Camacho já se posicionava em terceiro lugar, com 14\%, e não demonstrava a mínima vontade de desistir em favor de Mesa. Outras figuras da direita boliviana também estavam na disputa, entre as quais o expresidente Jorge Tuto Quiroga e o pastor evangélico Chi Hyung Chung (de origem sulcoreana), ambos com índices magros de intenções de voto, em torno dos $3 \%$ a $4 \%$. O candidato mais forte entre os opositores, Carlos Mesa, ainda parecia apresentar, àquela altura, fôlego para chegar à disputa presidencial em segundo turno contra o masista Arce. Nesse caso, acreditava-se que teria condições de, à frente de uma ampla aliança de direita, vencer a eleição, derrotando o candidato do MAS.

Para isso, no entanto, seria necessário um acordo com Camacho, que liderava as pesquisas em Santa Cruz e estava utilizando as eleições para fortalecer sua posição como líder regional e para ampliar o número de parlamentares sob seu comando. A retirada da candidatura, definitivamente, não fazia parte dos seus planos.

\section{Considerações finais}

O MAS, que ao longo de 2020 se reafirmou como a grande força política nacional, venceu as eleições presidenciais de outubro e conquistou maioria na Câmara dos Deputados e no Senado. Posteriormente, nas eleições subnacionais, conquistou a prefeitura de 240 dos 336 municípios e o governo de três dos nove departamentos (Estados). A votação, em outubro, foi marcada por fortes tensões, presença militar nas ruas, múltipla participação de observadores internacionais, mas não teve desestabilização.

A vitória de Luis Arce foi acachapante. No que se esperava uma disputa acirrada, o candidato do MAS venceu em primeiro turno com mais de 55\% dos votos, superior em mais de $25 \%$ ao segundo colocado. Além disso, obteve 21 das 36 cadeiras do Senado e 73 cadeiras de 130 na Câmara dos Deputados. Esses resultados geraram 
euforia entre as forças de esquerda na América Latina, como um símbolo do despertar de uma nova onda progressista na região.

O panorama político sul-americano, contudo, mostra-se bem mais complexo e fragmentado do que nos tempos em que a liderança de figuras carismáticas com Hugo Chávez, Néstor Kirchner, Luis Inácio Lula da Silva e Rafael Correa, juntamente com o próprio Morales, construíam na América do Sul um território de autonomia e de reforma social que ergueu como referência institucional a União das Nações da América do Sul (UNASUL), atualmente desativada (SILVA, 2019). No caso da Bolívia, o mandato de Luís Arce enfrenta um cipoal de desafios, a começar pelo espinhoso cenário econômico. Em contraste com a bonança global que favoreceu as exportações bolivianas na maior parte dos mandatos de Morales, o atual presidente enfrenta um contexto de preços baixos das commodities, o que afeta seriamente a economia do país. O valor das exportações bolivianas de petróleo e gás natural - a principal fonte de divisas da Bolívia - caiu pela metade nos últimos cinco anos, de US\$2,2 bilhões em 2015 para 1,1 bilhão projetados para 2020 (MACNELLY, 2021).

Mas a tarefa mais urgente do novo presidente é a de reverter o trágico atraso no combate à Covid-19, um amargo legado de sua antecessora. Nos primeiros meses de seu governo, Arce se lançou em um esforço intensivo para firmar contratos com laboratórios de diferentes países a fim de garantir as vacinas necessárias para imunizar a totalidade da população. Garantiu, dessa forma, o acesso a imunizantes como as vacinas Sputnik (russa) e AstraZeneca (britânica), juntamente com as remessas prometidas com base no convênio internacional Covax. Depois de praticamente um ano perdido com a negligência governamental diante a pandemia, a Bolívia passou a pôr em prática as orientações da OMS, por meio de uma estratégia estruturada sobre três pilares: vacinação em massa, imunização da população priorizando os segmentos com maior risco e coordenação entre as diferentes instâncias estatais e a participação da sociedade por meio de suas organizações (QUISPE BARRA, 2021).

Mas o desafio de Arce se tornou ainda mais complexo, pois logo em seu primeiro trimestre de governo a segunda onda da pandemia, de forma ainda mais agressiva, disseminou-se pelos países da região. Quando assumiu o país em novembro de 2020, a pandemia tinha custado a vida de 8.795 pessoas no país. Um ano depois, já são 19.062 vidas perdidas no total. 
Gráfico 3 - Taxa de Letalidade do Coronavírus na Bolívia - Média móvel da relação entre casos e mortes confirmadas de COVID-19

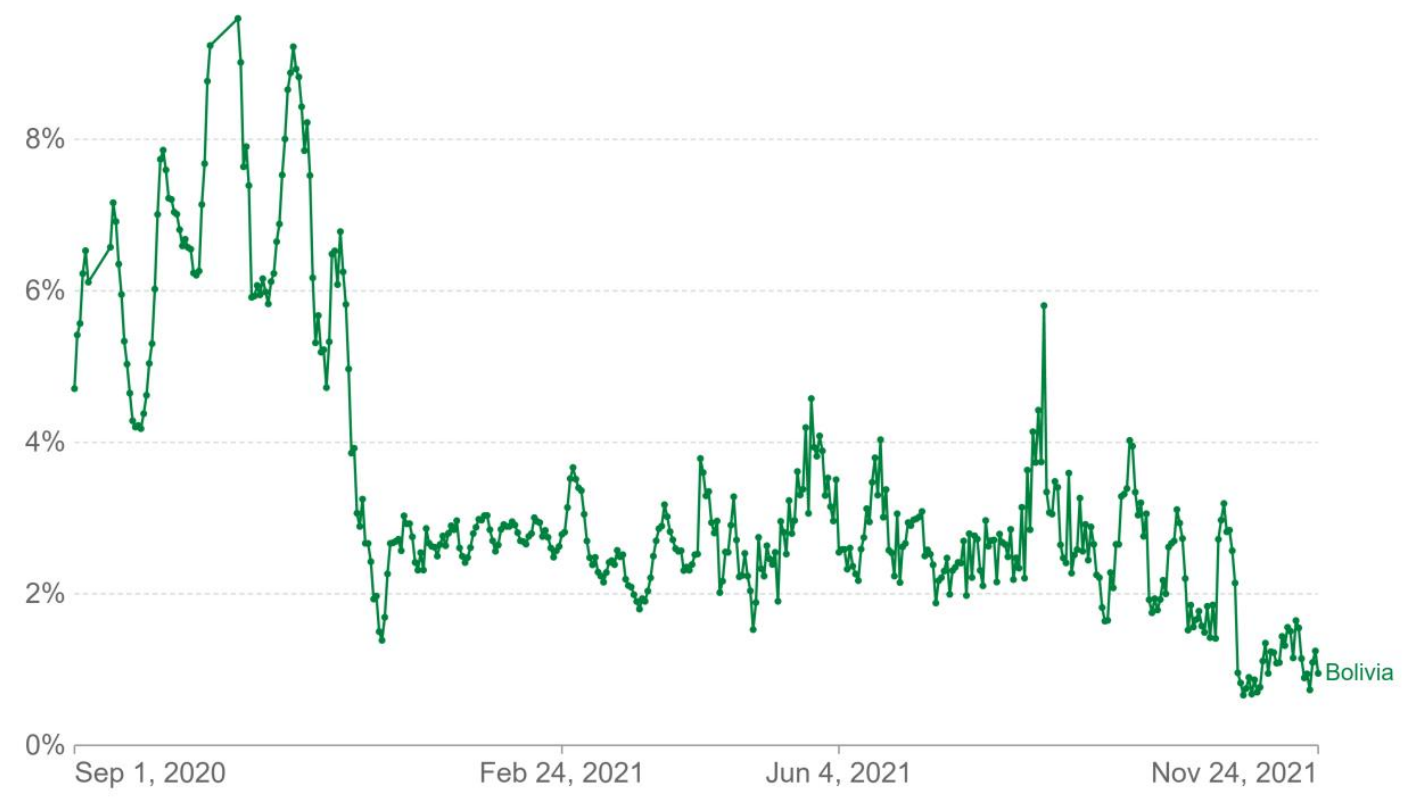

Fonte: Our World in Data. COVID-19 dataset.

A aposta na vacina tardou a ter efeito, tendo em vista a dificuldade de negociar contratos com os fabricantes, e o país ingressa no mês de novembro de 2021 com uma taxa de imunização de apenas $33 \%$ da população total. De toda forma, as políticas adotadas por Arce lograram contribuir para reduzir a letalidade do coronavírus no país. A taxa de letalidade do vírus em outubro de 2020 estava em torno de $9 \%$, chegando a aproximadamente $3 \%$ um ano depois - Gráfico 3 (OUR WORLD IN DATA). Aparentemente, a racionalidade passou a guiar a conduta dos governantes, mas a instabilidade política e os riscos da Covid 19 e suas variantes ainda pressionam o governo de Arce.

\section{Referências bibliográficas}


ALIAGA, Javier (2020). La crisis sanitaria y la pugna política dibujan una Bolivia camino "al desastre". France 24, $1^{\circ}$ de agosto. Acesso em 15/07/21 em https://www.france24.com/es/20200801-bolivia-covid-crisis-sistema-saludpolitica

ATAHUICHI, Rubén (2021). Reunión en la UCB en 2019: Scarpellini, Mesa y Quiroga eran el poder antes que Áñez. La Razón. 2 jun. Disponível em: <https://www.larazon.com/nacional/2021/06/02/reunion-en-la-ucb-scarpellini-mesa-y-quirogaeran-el-poder-antes-que-anez/>. Acesso em: 15 jul. 2021.

BARBOSA, G. F. (2021). Falta de vacina em países periféricos é prova do capitalismo funcionando. Brasil de Fato. 18 jun. Disponível em: < https://www.cartacapital.com.br/opiniao/falta-de-vacina-em-paises-perifericos-eprova-do-capitalismo-funcionando/>. Acesso em: 15 jul. 2021.

$B B C$ NEWS (2019). Elecciones en Bolivia: el TSE confirma la victoria de Evo Morales sin necesidad de segunda vuelta y está abierto a una auditoría sobre el recuento. 25 out. Disponível em <https://www.bbc.com/mundo/noticias-america-latina50179895>. Acesso em 10 nov. 2021.

BOLÍVIA (2020a). Decreto Supremo No 4179. Declara Situación de Emergencia Nacional por la presencia del brote de Coronavirus (COVID-19) y otros fenómenos adversos. 12 mar. La Paz: Gaceta Oficial del Estado Plurinacional de Bolivia.

BOLÍVIA (2020b). Decreto Supremo No 4199. Declara Cuarentena Total en todo el territorio del Estado Plurinacional de Bolivia, contra el contagio y propagación del Coronavirus (COVID-19). 21 mar. La Paz: Gaceta Oficial del Estado Plurinacional de Bolivia.

CAPONI, Sandra et al. (2021). O uso político da cloroquina: COVID-19, negacionismo e neoliberalismo. Revista Brasileira de Sociologia-RBS, v. 9, n. 21, pp. 78-102. DOI: https://doi.org/10.20336/rbs.774

CAZARRÉ, Marieta (2020). Presidente interina da Bolívia marca eleições para 6 de setembro. Agência Brasil. 22 jun. Disponível em: <https://agenciabrasil.ebc.com.br/internacional/noticia/2020-06/presidenteinterina-da-bolivia-marca-eleicoes-para-6-de-setembro>. Acesso em 10 nov. 2021.

CASTRO, Fabio S. M.; GUERRA, Sinclair M. G.; LIMA FILHO, Paulo A. (2021).

Lithium and vivir bien: Sovereignty and transition. In: RIVERA, S. V. (org).

Bolivia at the Crossroads: Politics, Economy, and Environment in a Time of

Crisis. Londres: Routledge. DOI: https://doi.org/10.4324/9781003147923

CEJIS (2020). Bolivia ante el COVID-19: ¿Los pueblos indígenas están en puertas de un etnocidio? 11 abr. Disponível em: <https://www.cejis.org/bolivia-ante-elcovid-19-los-pueblos-indigenas-estan-en-puertas-de-un-etnocidio/>. Acesso em 10 nov. 2021.

CEPAL (NAÇÕES UNIDAS - COMISSÃO ECONÔMICA PARA A AMÉRICA LATINA) (2021). La prolongación de la crisis sanitária y su impacto sobre la salud, la economia y el desarrollo social. Santiago de Chile, 14 out. Disponível em: $<$ https://repositorio.cepal.org/bitstream/handle/11362/47301/1/S2100594_es. pdf $>$. Acesso em 24 nov. 2021.

DOS SANTOS, Fabio Luis Barbosa (2018). Uma história da onda progressista sulamericana (1998-2016). São Paulo: Elefante.

EL PAÍS (2021). Cedla: Aumenta el trabajo informal en Bolivia. 07 mai. Disponível em: $<$ https://elpais.bo/nacional/20210507_cedla-aumenta-el-trabajo-informal-enbolivia.html>. Acesso em: 20 nov. 2021. 
FUNDACIÓN TIERRA (2012). Marcha indígena por el TIPNIS: la lucga em defensa de los Territorios. La Paz: Fundación Tierra.

FUSER, Igor (2016). Bolivia. São Paulo: Fundação Perseu Abramo.

FUSER, Igor; CASTRO, Fábio S.M. (2020). Bolívia: o golpe sob a prova das urnas. Socialismo e Liberdade, v.30, pp. 52-59. Disponível em: <https://www.laurocampos.org.br/2020/10/03/bolivia-o-golpismo-sob-provadas-urnas/>. Acesso em 25 nov. 2021.

G1 (2021). CPI da Covid: veja as principais conclusões do relatório final. 20 out. Disponível em: <https://g1.globo.com/politica/cpi-dacovid/noticia/2021/10/20/cpi-da-covid-veja-as-principais-conclusoes-dorelatorio-final.ghtml>. Acesso em 24 nov. 2021.

GARCÍA LINERA, Álvaro (2011). El Oenegismo, Enfermedad Infantil del Derechismo. La Paz (Bolívia): Vice-presidencia del Estado, Presidencia de la Asamblea Legislativa Plurinacional. Disponível em <http://vicepresidencia.gob.bo/IMG/pdf/el-oenegismo.pdf $>$. Acesso em 25 nov. 2021.

HERNÁNDEZ BERMÚDEZ, Orietta E. (2020). Bolivia em tiempos de la Covid-19. Cubadebate, 21 de abril. Acesso em 15/07/2021 em http://www.cubadebate.cu/especiales/2020/04/21/bolivia-en-tiempos-de-lacovid-19/

HUMMEL, Calla et al. (2020). Bolivia: lecciones sobre los primeros seis meses de la pandemia de SARS-CoV-2. Temas Sociales, La Paz, n. 47, p. 98-129, nov. Disponível em: $<$ http://www.scielo.org.bo/scielo.php?script=sci_arttext\&pid=S004029152020000200005\&lng=es\&nrm=iso>. Acesso em: 24 nov. 2021.

IDROBO, N; KRONICK, D. and RODRÍGUEZ, F. (2020). Do shifts in late-counted votes signal fraud? Evidence from Bolivia. University of Pennsylvania. SSRN. Jun., pp. 1-47. https://ssrn.com/abstract=3621475.

JOHNSTON, Jake (2019). Preliminary Analysis of the Findings of the Final Report on the OAS Audit. Center for Economic and Policy Research (CEPR). $12 \mathrm{dez}$. Disponível em: <https://cepr.net/wp-content/uploads/2020/02/BriefingJohnston-OAS-Audit-2019-12-12.pdf >. Acesso em 10 nov. 2021.

LA POLÍTICA ON LINE (2020). Bolivia se sumerge en un caos sanitario mientras Áñez se resiste a dejar el poder, 19 de junho. Acesso em 15/07/2021 em https://www.lapoliticaonline.com.ar/nota/127415-bolivia-se-sumerge-en-uncaos-sanitario-mientras-anez-se-resiste-a-dejar-el-poder/

LA REPÚBLICA (2021). Especial Covid-19. Bogotá, Colômbia, atualização de 25 nov. Disponível em 〈https://www.larepublica.co/especial-covid-19/bolivia >. Acesso em 25 nov. 2021.

LAMBERT, R. (2019). En Bolivie, un coup d'État trop facile. Le Monde Diplomatique (December): 9. Disponível em: <https://www.mondediplomatique.fr/2019/12/LAMBERT/61150>. Acesso em: 10 jul. 2021.

LEHOUCQ, Fabrice (2020). Bolivia's Citizen Revolt. Journal of Democracy, vol. 31 no. 3, pp. 130-144. Project MUSE, doi:10.1353/jod.2020.0050.

LONG, G. et al. (2020). What Happened in Bolivia's 2019 Vote Count? Challenge, 63:3, pp. 19-331, DOI: 10.1080/05775132.2020.1711490

MACNELLY, Angus (2021). The Uncertain Future of Bolivia's Movement Toward Socialism. April 15. New Labour Forum. Acesso em 15/07/21 em https://journals.sagepub.com/doi/full/10.1177/10957960211006408 
MANETTO, Francesco (2019). Alerta na Bolívia pela impunidade aos militares que reprimirem protestos. El País. 18 nov. Disponível em: <https://brasil.elpais.com/brasil/2019/11/17/internacional/1574014107_965320. html >. Acesso em: 15 jul. 2021.

MAYER, Marianela (2020). El coronavirus causa en Bolivia una triple crisis: sanitaria, económica y, sobre todo, política. Telam, 16 de outubro. Acesso em 15/07/21 em: https://www.telam.com.ar/notas/202010/525606-el-coronavirus-causa-enbolivia-una-triple-crisis-sanitaria-economica-y-sobre-todo-politica.html

MAYORGA, Fernando (2020). "Elecciones ya?”¿el MAS recupera la iniciativa? Nueva Sociedad, junho. Acesso em 15/07/21 em https://nuso.org/articulo/bolivia-de-la-pandemia-las-elecciones/

MINISTERIO DE LA PRESIDENCIA - BOLIVIA (2020). Gobierno presentó Bono Universal, amplió Bono Familia a colegios particulares y anunció créditos blandos a empresas para frenar la crisis por el coronavirus. 14 abr. Disponível em: <https://www.presidencia.gob.bo/index.php/prensa/noticias/1252-gobiernopresento-bono-universal-amplio-bono-familia-a-colegios-particulares-y-anunciocreditos-blandos-a-empresas-para-frenar-la-crisis-por-el-coronavirus>. Acesso em: 10 nov. 2021.

MIRANDA, Boris (2020). Coronavirus en Bolivia: cómo la pandemia cambió todo en la carrera por elegir al sucesor de Evo Morales. BBC, 03 de maio. Acesso 15/07/2021 em https://www.bbc.com/mundo/noticias-america-latina-52510570

MOLINA, Fernando (2020). Ministro da Saúde da Bolívia é preso por compra superfaturada de respiradores. El País. 20 mai. Disponível em: <https://brasil.elpais.com/internacional/2020-05-20/ministro-da-saude-dabolivia-e-preso-por-compra-superfaturada-de-respiradores.html > . Acesso em: 10 nov. 2021.

QUISPE BARRA, Armando (2021). Un año de pandemia en Bolivia: Del caso respiradores a la inmunización masiva. Agencia Boliviana de Información (ABI), $1^{\circ}$ de março. Disponível em $\langle$ https://www.comunicacion.gob.bo/?q=20210305/31929). Acesso em 15 jul. 2021.

OUR WORLD IN DATA. Covid-19 dataset. Disponível em: < https://ourworldindata.org/covid-cases>. Acesso em: 15 jul. 2021.

PNUD BRASIL (2021). Desigualdade na distribuição de vacinas prejudica recuperação econômica mundial. 22 jul. Disponível em: <https://www.br.undp.org/content/brazil/pt/home/presscenter/articles/2020/desig ualdade-na-distribuicao-de-vacinas-prejudica-recuperacao-ec.html >. Acesso em 24 nov. 2021.

RAMOS, Daniel (2020). Bolivia investiga corrupción en compra respiradores por coronavirus, despiden a ministro Salud. Reuters, 20 mai. Disponível em $<$ https://www.reuters.com/article/salud-coronavirus-bolivia-corrupcionidLTAKBN22W33J >. Acesso em 15 jul. 21.

RIVERA, Soledad V. (2019). Political networks and social moviments: Bolivian StateSociety relations under Evo Morales, 2006-2016. New York: Berghahn.

RODRIGUEZ, Andrónico (2020). Entrevista a Diálogos do Sul, 21 de agosto. Acesso em 15/07/21 em https://dialogosdosul.operamundi.uol.com.br/americalatina/66309/governo-boliviano-usa-midia-e-justica-para-impedir-candidaturade-arce-diz-lider-sindical

SCHALVEZON, Salvador (2011). El conflicto del Tipnis y los derechos plurinacionales em Bolivia. Teoria e Cultura, Juiz de Fora (MG), v.6, n. 1 e 2, p. 
73-84, jul/dez. Disponível em: < https://periodicos.ufjf.br/index.php/TeoriaeCultura/article/view/12157>. Acesso em 25 nov. 21.

SILVA, Fabricio Pereira da (2019). América Latina em seu labirinto - Democracia e autoritarismo no século XXI. Rio de Janeiro: Ponteio.

SPUTNIK (2020). El Gobierno de Bolivia crea bono familiar extraordinario por coronavírus. 18 mar. Disponível em: <https://mundo.sputniknews.com/20200318/el-gobierno-de-bolivia-crea-bonofamiliar-extraordinario-por-coronavirus-1090831207.html>. Acesso em 10 nov. 2021.

STEFANONI, Pablo (2020). Las lecciones que nos deja Bolivia. Nueva Sociedad, Buenos Aires, mar. Disponível em <https://nuso.org/articulo/Bolivia-EvoMorales-elecciones/>. Acesso em 15 nov. 2021.

SVAMPA, Maristella (2021). A pandemia do ponto de vista da América Latina: nove teses para um balanço provisório. Nueva Sociedad, n. 2021, ago.-set. https://nuso.org/articulo/pandemia-do-ponto-de-vista-da-america-latina/

TELAM (2021). Bolivia llevará a la OEA a expertos que refutan la denuncia de fraude electoral. 20 out. Disponível em: <https://www.telam.com.ar/notas/202110/572354-bolivia-oea-elecciones2019.html >. Acesso em: 24 nov. 2021.

THE NEW YORK TIMES (2019). 'This Will Be Forever': How the Ambitions of Evo Morales Contributed to His Fall. 13 nov. Disponível em: < https://www.nytimes.com/2019/11/11/world/americas/evo-morales-boliviaresignation-coup.html>. Acesso em: 15 nov. 2021.

THE NEW YORK TIMES (2020). A Bitter Election. Accusations of Fraud. And Now Second Thoughts. 09 nov. Disponível em: < https://www.nytimes.com/2020/06/07/world/americas/bolivia-election-evomorales.html>. Acesso em: 15 nov. 2021.

UOL (2021). Lula sobre 500 mil mortos por covid-19: 'Isso tem nome e é genocídio'. 19 jun. Disponível em: <https://noticias.uol.com.br/saude/ultimasnoticias/redacao/2021/06/19/lula-500-mil-mortos.htm>. Acesso em: 15 jul. 2021.

VASSALLO, Guido (2020). Bolivia: a un año de la masacre, Sacaba recuerda a sus víctimas. Página 12.16 nov. Disponível em: $<$ https://www.pagina12.com.ar/305985-bolivia-a-un-ano-de-la-masacre-sacabarecuerda-a-sus-victima>. Acesso em: 15 jul. 2021.

VILLCA, Claudia (2020). Persiste la inexistencia de barbijos en farmacias y la ciudadanía opta por los artesanales. La Razón. 07 abr. Disponível em: < https://www.la-razon.com/sociedad/2020/04/07/persiste-la-inexistencia-debarbijos-en-farmacias-y-la-ciudadania-opta-por-losartesanales/?fbclid=IwAR2UH1ruDd0587y4XnYhXTFUDkQ8ZqNifzSBtBJMB fj5g61vWDPyjZId1Bk>. Acesso em 20 nov. 2021.

WORLD BANK. The World Bank data. Disponível em: < https://data.worldbank.org/indicator/NY.GDP.MKTP.KD.ZG?locations=1W> . Acesso em 15 jul. 2021.

ZIBECH, Raúl (2019). Bolívia: um levante popular aproveitado pela extrema direita. Revista IHU On Line. 13 nov. Disponível em: <http://www.ihu.unisinos.br/78noticias/594307-bolivia-um-levante-popular-aproveitado-pela-extrema-direitaartigo-de-raul-zibechi>. Acesso em: 15 nov. 2021. 
ZIBELL, Matías (2020). Mortos em casa e cadáveres nas ruas: o colapso funerário causado pelo coronavírus no Equador. BBC News Brasil. 1 abr. Disponível em: $<$ https://www.bbc.com/portuguese/internacional-52129845>. Acesso em: 15 jul. 2021.

Artigo recebido em: 15 de julho de 2021.

Aprovado em: 26 de novembro de 2021.

DOI: $10.12957 /$ intellectus.2021.61137 